\title{
Socio-Economic Impact And Status Of The Islamic Perspective Of Veil
}

\author{
Shagufta Jahangir \\ \& \\ Asma Manzoor \\ Women's Studies \\ University of Karachi \\ Imran ul Haq Kalyanvi \\ Department of Qur-o-Sunnah \\ University of Karachi
}

\begin{abstract}
The Persian language word 'Purdah' and in Arabic 'Hajab' used for veil. Veil used by women for being segregation, protection and escaped from men. In one way or the other veil not invented by Muslims. It continuously used in ancient as well as modern civilizations by women. Developed nations have blamed the use of veil an obstacle in the process of development. Therefore, modern nations have struggled to get rid of the use of veil. They argue that it is a sign of slavery for women and it is an obstacle in the path of development. The modern secular or liberal educated Muslims considered veil as the biggest obstacle for social and economic development. It makes a woman helpless, as being zanjir (chain) in her feet. It has become an obstacle in the process of development for women. It is consider as a tool for segregation among men and women. The so-called Muslims of the modern era are trying to introduce changes in religion by imitation the modern nations of the world. In particular, ways for Muslim woman use of veil in Islam is must. It is a right provided her by religion. It provides her strength. Veil is a sort of obstacle that the splitting of Muslim space between men and women, and has gone auxiliary in creating the gap both in public and in private today. Muslim females deem that veiling is a constraint of modesty and a mark of duty to God; other women squabble that the veil is pinpointing of defense from the patriarchal prioritization of women's corporeal and sexual pleasant appearance. In the Holy Quran word, 'Hajab' is use 7 times. Women adopt Islam is against domination and forceful practice of veil, as a part of teaching of Islam as a protection. This article aims at: (1) historical background of veil and its existence in civilizations, (2) Socio-Economic impact of it on women, (3) Meaning and interpretation of veil in Islamic context, followed by concerted bibliography.
\end{abstract}

Keywords: Veil, Economic Development, Civilizations, Obstacle, Segregation.

$$
\begin{aligned}
& \text { تخصص }
\end{aligned}
$$

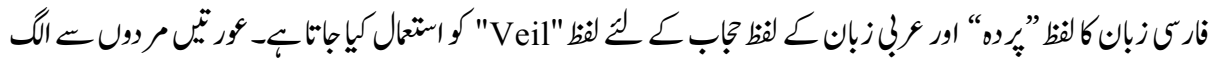

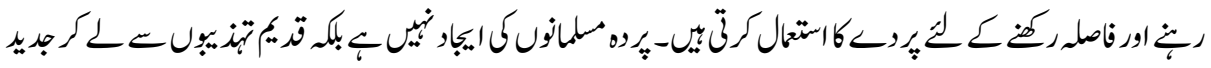




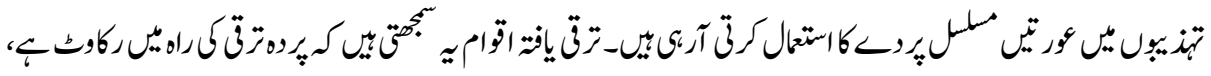

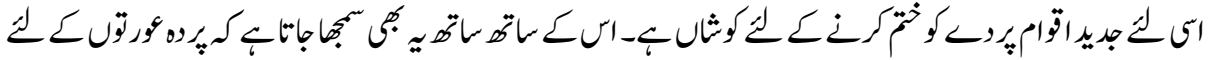

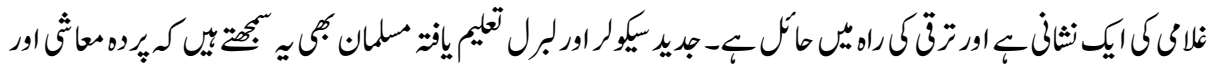

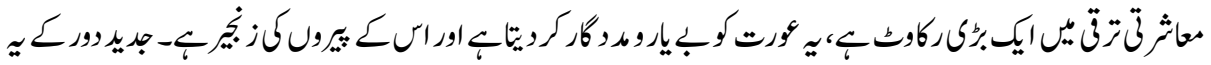

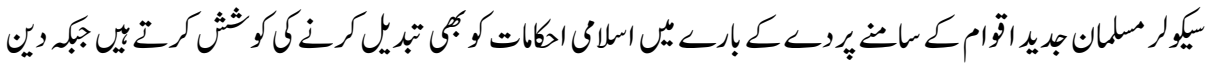

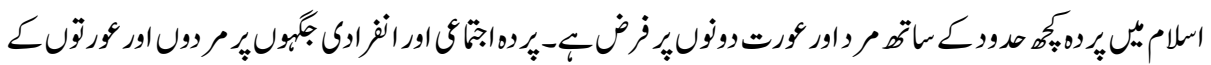

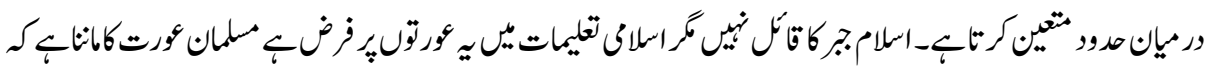

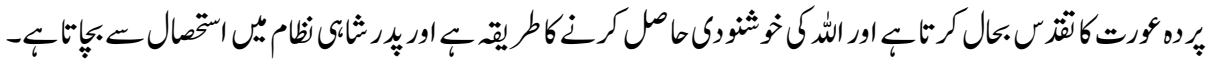

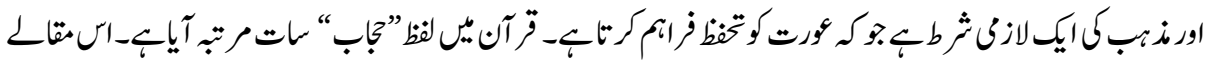

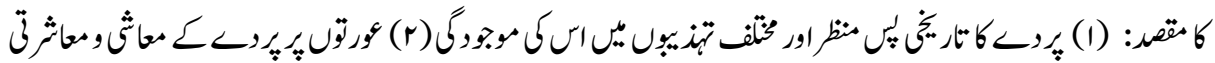

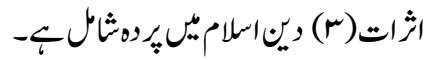

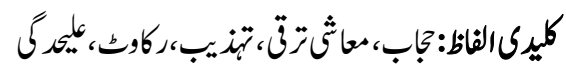

\section{Introduction}

The Persian language word 'Purdah' in Arabic 'Hijab' in Hindi 'Pardah' (Britannica, 2000), 'Turban in Turkish, Chador in Iran and Afghanistan, Hijab in Egypt, Middle Eastern countries and North Africa (El Guindi, 1999; Ahmed, 1992; Mernissi, 1987-1991; Papanek, 1982) is used for veil. Its use started with the emergence of conscience in human beings. Women for being escaped from men have used veil. In one way or the other veil has been continuously used in ancient as well as modern civilizations by women. Woman did not put veil on their dress in Arab. They could not live separate from men. They used to attend all celebrations with men. They used to go to masque, prayed and gave speeches and sermons in mosque. However, after the establishment of Islamic kingdom and invasion of other nations around them i.e. Romans and Persian the Muslims of Arabs started adopting their culture. The Arab culture was invaded and amalgamated with the Roman and Persian cultures and civilizations. This was an influence of Persian and Qastintanain empires on Arabs. It promoted segregation of men and women among the Arabian culture and promoted use of veil. It also promoted the system of separate rooms for women in the homes (Mathura, 1996:15). It is sad to say that the Arab Muslims adopted the same out dated traditions and customs of other civilizations when they capture them and ruled over them. Later when Muslims came to India and settled, here they brought with them the same adopted customs of veil and other Indians who converted and accepted Islam as a religion adopted it. Developed nations have blamed the use of veil an obstacle in the process of development. Therefore, modern nations have struggled to get rid of the use of veil. They 
argue that it is a sign of slavery for women and it is an obstacle in the path of development. It has become a prohibition for the use of fashion. It makes a woman helpless, as being zanjir- in her feet. It has become an obstacle in the process of development for women. It is also considered as a tool for segregation among men and women. The so-called Muslims of the modern era are trying to introduce changes in religion by imitation the modern nations of the world. Iqbal (1935) has explained this act of the Muslims in words that they don't change themselves instead change the Holy Quran. The modern secular Muslims considered veil as the biggest obstacle for social and economic development. Whereas, for adult Muslim women it is mentioned in the Holy Quran, in several ways to adopt veil to cover body from men. In particular, ways for Muslim woman use of veil in Islam is must. It is a right provided her by religion. It provides her strength. The comparison between Islamic and western societies is very complicated even my opinion Islamic and western societies are homogenous both are extremely differentiated because many Muslim women think that veil is a thing of pride, politicized act and it is not an icon of male authority over them. On the other hand according to (Mahl, 1995) many women of Iran and Saudi Arabia where women are obliged to wear veil, feel cowed and are divergent it but they feel apprehensive that if they unveil then anti- fundamentalist sentiments possibly will be interpreted as anti-Islamic. In the Holy Quran, word 'Hijab' is used 7 times (Donzel, 1978).

\section{Historical Background of Veil and its Existence in Different Civilizations}

According to Oxford Dictionary of Islam (Esposito, 1995) the traditional Muslim women face, head or covered body of several facts across time and space. Veil has a long history in different civilizations and societies. so the meaning of veiling has change from one civilization or society to another, It purely depending on myths, norms, customs culture, political and social behaviors. The roots of veil are not associated with Islam. Veil does not invent by Islam (Ahmed, 1992; El Guindi 1999; Macleod, 1991, Reeves, 1989). According to (EI Guindi, 1999) Muslims traditionally practices veil contemporary antedates Islam. (EI Guindi, 1999) find out that elite Muslims women practiced veil of the Devious and Persian kingdoms through Arab conquest. Historically veil among women started in the 13 century BCE. Veil and it emerged from the Assyrian kingdom (Greaber, 2011). In the Assyrian, Byzantine, and Persian asanian empires, the veil was the symbol of honor and prestige. According to Assyrian Law wealthy and well off women use veil as a symbol of status while prostitutes, slaves and peasant women are strictly prohibited to veil as punished (El Guindi, 1999). According to (Goto, 2004) married women under the protection of their husband and unmarried women under their father or brother protection are essentially covering their heads in public and private places while slaves and prostitutes are prohibited from it. (Hourani, 2005) argue that in the 1930's decade the elite peoples adopt the Western culture in their lives and unveiled their women while non-Muslim minorities of Middle East countries begun veil practiced in $19^{\text {th }}$ century. 
(Shaarawi \& Badran, 1987) find out that an Egyptian elite women Huda Shaarawi forbidden the practice of veil after attending an International feminist meeting. This is the starting of unveiling of Cairo women and entrance of Western dress code in Egypt. (Bayat, 2007) described that $80 \%$ Cairene women practice of veil in different forms. (Brue \& Marchese, 2000) described that in 1970's veil is seldom present in Turkey while (Rheault, 2008) argue that $45 \%$ women in Turkey practice of veil in communal places. Veil is forbidden in 1924 in all Turkey Universities and Government establishments. In 2008 veil revoke in Turkey. (Smith Hefner, 2007) described that in 1970's only 3\% National universities Muslim girls practice of head scarf while in 2002 the percentage increase $60 \%$ in Indonesia. The women of Tunisia (Waltz, 1986) and the women of Pakistan (Afzal Khan, 2007) also described that veil is adopted in these countries. According to (Ali, 2005) veil is upsurge in America and Europe after 1990s. (Morin \& Horowitz, 2006) argue that 53\% British, 43\% Spain, 54\% Germany, Netherland 51\%, 13\% French Muslim women practice veil even in 2004 France bans headscarf at public schools for Muslim women. France and Belgium also bans on face veil for Muslim women. According to (Bremner, 2010) a political movement is started to ban veil in Denmark, Egypt, Italy, Netherland and Switzerland (Knauss, 1987) described that in Arab women are trickily prohibited to unveil.

In the seventh century when Islam is advent, at that time veiling was present GrecoRoman, Judaic, Persian, Byzantine, and Balkan societies. According to (Esposito, 1995; Sherif, 1987) that veiling is present in the ancient near east and Arabia before the Islam. According to (Nashat, 2003b) veiling is the consequence of conquered societies of Greco-Roman, Judaic, Persian, Byzantine, and Balkan in Islam.(Schmidt,1989) find out that veiling is the social and cultural practice which comes in Islamic circle from other civilizations. Before the advent of Islam in seven century, veiling is present in Cyprus, Greco- Roman, Persian, Byzantine, Judaic and Balkan societies. According to (Misha \& Shirazi, 2010) conducted a study on veiled and unveiled Muslim women. Those most Muslim women decided to wear the hijab after researching its purpose in Islam while (Stillman, 2003) Muslims practice veil in the twentieth century as a sign of coercion and backwardness.

At the time of its peak, Cyprus was considered one of the greatest kingdoms of the world. It seems that the conditions, situation, and rank of women were the lowest from the begging to the peak and fading of the civilization and kingdom. At the peak of the civilization noble and rich women used to practice veil. In their homes, separate rooms for women and men existed. There were no combine meetings and celebrations in this civilization and women remained in veil (Maudodi, 1999). Men and women gracefully used to live whole life after marriage. It was most advance stage of the Cyprus civilization. Although, women, but men in the jurisdiction of veil were practicing veil 
used to enjoy more powers than women did. Men used to enjoy relations with the widows because they were not considered bad. According (Maudodi, 1999) slowly the illegal relationship among women and men started growing and this became one of the reasons for the downfall of the great civilization. Mixing of men and women, sex, and relationship of both sexes, combine celebrations according to philosophers and thinkers of these civilizations was considered necessary and declared as development of art, civilization and social development. Artists made statues of unveiled, naked and nude women and declared it as art. Scholars in educational institutions declared unveiled and nudeness of women as part of strong relationship of friendships. This unveiling, nudeness and nakedness of women provided chances for illicit and sexual relationship and provided reasons for the down fall of the great civilizations (Maudodi, 1999). According to (G.Mariti, 1769) Muslims Cypriot women was covered their face by pulling a corner of the headscarf across their nose and mouth

The roman civilization was considered as one of the greatest civilizations of its time. To corroborate that the veil was the standard mode of dress that symbolized virtue or chastity for Roman matrons according to (Hughes, 2007) during the Augustan period (27 BCECE-14). In roman civilizations relations of men and women was considered valid only after marriage. Veil was not practiced during the democratic period of roman civilizations but women were watched and guarded very closely. A very high character was maintained at this time of the civilization. A very high ethical level of character prevailed at this time in this civilization. Dignity and sexuality of women was considered a high level of character. When new ideas and novelty came in the civilization widows were given high ranks and stats. (Maudodi, 1999) explained in his book "veil" The high status of Widows became one of the reasons for the downfall of the Roman civilization and a powerful empire. According to (Maudodi, 1999) down fall of the Roman Empire and civilizations started very soon after the end of veil and given the values and status in the society to widows, unveiled Naked, and nude women.

In India, an old Hindu civilization is considered as one of the oldest civilization of the world. Status of women in Hinduism is one of the lowest as compared to other civilizations. According to Jawaher Lal Nehru as explained in a book "history of the world History" nothing is more dangerous, bad and poisons than a women not even a fate, typhoon, poison of snake, poison, death, hell etc. (Nehru, 1950). According to Rug Vida in Hindu religion it is mentioned that God made you women, so you shall lower your gaze and do not look at men. Keep your feet close, cover your hair and disclose the garments, should not disclose the garments, which should conceal with the veil (Rig Veda, Book \# 8 Hymn 33, mantra 19-20). According to (Rug Veda, Book \# 10 Hymn 38, and mantra 30) "It is not good, that man covering this thigh with female garment" When Ram saw the Paruslio Ram coming, he told seta keep yourself in the veil and lowers your gaze (Mahan Vera Chita Act 2 p. 71). But socio culturally there is no binding on women 
for wearing of veil in the Hindu civilization. In Indian Civilization, status of women is at the lowest rank as compared to other civilizations of the world (Parkas, 1912:378-379). In Hinduism woman was considered a very lowest status and a commodity. It was sold and purchased in the open market and for that cheapest commodity; there wasn't any veil.4 .Hindu leave the Muslims values and go back to original values of Hindus in which women are honored as goddesses not veiled as chattels or temptresses. According to (Afary Janet; 1996) Jewish and Christian women practice the veil. (Stillman, 2003) described that Christian start veiling from 1890. According to (Halliday, 1994; Mernissi, 1991) in predominate Islamic society, demonstration of the female body has many facets, but Islam received women under veiled position. (Hargreaves, 2007) describe veil is a weapon of male to control women.

\section{Socio-Economic Impact of it on Women}

Social categorization is essential to social recognition. (Hewstone, Hantzi, \& Johnston, 1991) Implies that gender sexuality describe the role of men or woman in the societies. Liberal feminist suppose that Islamic veil restrict women to participate in social, cultural and economic activities while veiling is a significant economic choice and not invented by Muslims while veil is a political, economic and social issue and women are reluctant to talk about veil (Williamson \& Ahmed, 2007). According to (Blaydes \& Linzer, 2008) that veiled working women are daily thoroughly physically screen out in foreign firms and employers in Indonesia, Turley, Egypt and Lebanon specially in tourism, hospitality and media industry. After the event of $9 / 11$ in non-Muslims countries economic and socially veiled women are faces too much problems due to veil in educational institutions and job searching (Omkar, 2007; Ali, 2005) while according to (Ahmed, 2005) that after 9/11 Muslim women practice veil to show their religious identity.

Western societies suppose that veil directly declines the socio-economic activities of women. There is a unanimously held view in the literature on womanhood that the phenomenon of veiling in Islam is associated with the oppression of women. While in reality patriarchy, male domination, gender discrimination, bread earners and unequal treatment with women are not associated with Islam. Islam provides equality and equity to men and women. (Afshar, 1985; Odeh 1993) find out that the status of Muslim women in almost Eastern countries are as subordinat position while (Brenner 1996; El-Guindi 1981, 1983; Hessini, 1994; Kadioglu, 1994). Argue and claim on this statement. According to (Cutrufelli, 1983) Women rights movements from some decades describe the gender inequalities which are arise with gender. (Ahmed, 1992; Dwyer, 1999) pointed out that veiled women to be feared and to be respected. (Gruenbaum, 1991; Hoodfar, 1991) find out that the veil strictly prohibited women to enter in any socio-economic activities. (Razack, 2004) find out that gender rules and customs of Islamic society represent deficit civilization which needs to be modernized. 
Islam did not explicitly prohibit women from working it direct women towards professions where there would be less contact with the other sex. Islam provides specified division of work between genders. Quran implies that superiority is belongs to men in the domestic and political fields. (Elwan, 1989) also find out that women should not proactive in economic activities while (Balkhair, 2010) are emphasize that Muslim women did not prohibited from working or to seeking job for earn money and prays. She also argues that a woman is burdanized in this situation that women performed inside and outside the home. (T.Baydoun, 1985) provide an example of Um-Alrabee, who performs in the public activities of the society. Religious perspective implies that women do work as a labor force but keep in their minds as a Muslim women "Do not be condescending and talk much of your kindness because Allah has preferred you to others. Men have the right to what they can earn by their efforts, and women have the right to what they earn also". This quotation from the Quran indicates that the Quran allows women to work and to earn their living, since it has given them the same right as men to what they earn.

The situation seems to be reversed in the case of veiled Muslim women living in nonMuslim countries; the veil makes them highly visible in the public sphere, which puts them under double pressure: on the one hand, they are subject to the community pressure since they are afraid to be rejected by their own group if they do not cover. On the other hand, they suffer from the pressure of popular stereotypes fostered in non-Muslim countries and according to which veiled Muslim women are oppressed, uneducated, and vulnerable. Such twofold pressure is manifested not only in the West29, but also in the case of veiled Muslim women from Romania, as our study demonstrates. According to (Kader, 1984) the word "Veil" is the wearing of a head - gear that covers the hair and lower part of face. This religious, social and cultural practice is very controversial in the Western countries. (Read, 2002) notice that this is the world symbol of oppression on women. (Hargreaves, 2000) find out that In Kuwait women are tolerable to wear nonprovocative outfit without a veil in public places. While in Saudi Arabia and Iran veil is, enforce on women. In the era of Taliban veil like Saudi Arabia is also present in Afghanistan.

\section{Meaning and Interpretation of Veil (Islamic Perspective)}

For Muslims Islam is not a religion alone, but a perfect way of life for them. Islam has instructions for women to protect themselves and not being nude and naked but covers their body parts in clothes, put veil and Hijab on it, especially cover sexual parts of the body. Veil is a sign and symbol of Muslim character. It protects from social conflicts. It creates social rules and regulates stages of life and harmony among them. It helps in performing social, cultural, political, and economical and sexual relations. It stands as a pillar in the sexual development. Evolution of human lives and human civilization depends on inner and outer implementation of veil in human beings. It protects men and 
women from rapes' and sexual exploitation. It is for both men and women to practice and save themselves from being victims of unethical practices of lust, sex and altruism. It protects from conflicts and helps to get sexual perfection and satisfaction. According to (Droogsma, 2007) veil helps as a continuous corporeal cue of religious treatments for performance.

The prophet Muhammad PBUH declared as under. "Tell the Momin men to keep their eyes downwards to protect their dignity and respect; it is a way for their purity." Tell the Momin women to keep their eyes downwards. The prophet Muhammad PBUH said the same for the women. "Tell the Momin women to keep their eyes downwards to protect their dignity and respect; it is a way for their purity." Button up their veil in front of their breasts. Keep it secret from men, husbands, father, sons, brothers, nephews, and other relatives as well. Tell these women to keep themselves away and protect themselves and secret body parts from servant men in the home who have nothing to do with the employer women. Women must also keep them away and in veil from boys who are yet not aware of the women secret matters. Order these women not to step their feet on the floor in a way to create noise, otherwise, in this way their beauty escaped in side clothes may not be disclosed

In Islam, women as well as men are being advised to keep their sex organs under veil. All the time at any place they are instructed to keep them under veil, not supposed to disclose or unclothed their secret organs that promote, instigation or stimulate lust for sex in others persons male or females. In special case, men and women are allowed to show them to doctors for treatment. It is also allowed to those organs to judges in case of any legal requirement. Under this rule, men from men and women from women must also keep their sex parts of their body in veil. Whole body of a woman excluding her face and hands are included in sex organs. Sex organ of men included from belly button 'naf' till knees (half of the lower body till his knees). In 'Surrah Al-Nur' there is a complete instructions about the veil of sex organs. The veil of sex organ is also from unmarried men.

\section{Islamic Perspective of Veil}

There are two Surrah of the Quran in which specific narration about clothing.

1. Surrah Al-Nur (Restruction of eyes and prohibition of show of regalia)

2. Surrah Al-Ahzab (Talking inaudibly and self-effacingly, Modesty in clothing, Enduring within the house)

In Surrah Al-Nur, Verse 24:31:

Tell the male believes among you that they are to lower their gaze when in the company of others and preserve their own modesty. Sexual 
modesty is better those who believe, and more conductive to purity. In addition, Allah is perfectly well aware of all that you do "Turner $(1997: 211)$

In the next verse 24:32:

Tell the female believers among you that they too are to lower their gaze when in the company of others and preserve their own modesty. They are not to make a display of there either natural beauty or their artificial ornaments: their legs are to remain covered, except for those parts exposed naturally when walking and they are to keep their hair covered with a scarf, which should be tied or pinned under the chin. They may display their beauty to no one except their husbands, their fathers, their husbands fathers, their sons their husbands sons, their brothers, theirs brothers sons, their sisters sons their maids, their slaves, male servants in their household who are free of all carnal desire and Childers who have no sexual knowledge. Women believers must take care not to draw attention to them by walking in such a way that whatever lies beneath their outer garments becomes exposed. And $\mathrm{O}$ you believe! Turn towards God in a spirit of reconciliation and dress yourselves in modest attire so that you may escape the punishments of the hereafter and attain eternal felicity in the garden of Paradise.

In surrah Al Ahzab, Verse 33, 34 and 60:

... [If] you continue to fear God and do good works, you will remain on a different plan to that of other women. Thus speak quietly and modesty when conversing with strangers; do not make a show of your voice least one of the refugees in whose heart there is a disease be smitten with desire. In order to preserve your God fearing character, speak only of serious matters when conversing with strangers; do not broach topics of a sexual nature least their passions become inflamed. While you may possess the maturity for such discussions, they may not, $(33: 33)$

"Remain calmly and quietly in your houses and do not display yourself from the windows doorways and roofs, as was the custom of women in the age of ignorance" (33:34).

"O Prophet! Tell your wives and daughters, and all believing women, to dress modestly when leaving the house: They should wear a clocklike outer garment or a veil, which they are to wrap around themselves in order to conceal their figures. Their dress serves their identity. Those 
as women of modest mien for who intimate contact with is strictly forbidden, thus helping to prevent harassment and intimidation. In blocking the path to errors and misdeeds God demonstrates His forgiveness and His Mercy" (33:60) Turner (1997:252-254).

There are four Imams in Islam according to them:

- Imam Abu Hanifa: a stranger is not allowed to stare at other women but he can see her face

- Imam Shafi: all parts except face and hands of woman should be veiled

- Imam Humbal: except women face all body should be veiled.

- Imam Malik: all parts of women's body should be veiled except her both hands and face (Sheikh, 1987:127)

In light of teaching of Islam there are two schools of Muslim (thought) scholars. One is in favor of complete veiling of women and another is not. Those who favor veil are providing references of the Holy Quran and Hadits in favor of their opinion that all parts of her body must be fully covered. Second groups comprising on those who are in favor of women veil but they agreed that woman can take her face and hands out of the veil to perform her daily activities and essential work of her life. Because several socioeconomic and religious duties and functions cannot be performed in veil, so they are bound to unveiled face and both hands. Incase if all parts of woman's body are fully covered she must be in a big trouble fulfilling her daily duties. Therefore, they can unveiled their face and hands for doing work, but while unveiling them (face and hands) Allah has order for a woman that eyes of a woman should be downwards. In Sura-e-Al Ahzab Allah says, O prophet tell your wives and daughters and Muslim women to put on themselves their Chadirs (shawls), it is good to be recognized by others, rather to be teased by others (Sura-e-Al Ahzab:59).

Islamic teaching encourages woman to perform all matters of her life but in the light of teaching of Islam and ethical boundaries. Her parts of body especially parts that naturally attracts men must be covered properly when coming out of her home (Al Quran, 21:23---) and (Sura-e-Al Ahzab, 23---).

Veil for Muslim woman is an order from God. Muslim women are supposed to keep their body parts secret. Naked unclothed body parts of a woman put men in temptation. Therefore, women are supposed to clothe their body parts in such a way that they are not visible to men. According to Islamic teaching women are instructed to cover them with veil and must keep themselves away from men. A veiled woman is forbidden for men like a for-bidden tree. Islamic veiling as a social and religious requirement for all women was a new concept that took a long time to become institutionalized and was for the most part an urban practice. 
Islam allows women to come out of home in case of leave her whole body are fully covered with properly dressed and all parts of her body are fully covered. The Islamic meaning of the veil differed from the meanings assigned to the veil in the pre-Islamic era, marking neither social standing nor marital status. The Islamic veil signified modesty

In addition, was required for all women. All parts beauty parts that can attract others must be fully covered. These obligations are imposed for increasing the respect and dignity of women. Man and woman must come out of their homes in such a manner that the honor, respect, dignity, polity, purity, and status of a woman must be shown in such a manner that an eye of a man must remain at least a kilometer away from her. A woman in Islam is allowed to move out of her home but in a respectful manner. She must put on her body an honorable dress. There is complete instruction and dress code for women given in Holy Quran in Sura-e Ahzab (Maudodi, 1999:279). According to the Prophet Muhammad (PBUH) that Allah has permitted to come out of your homes to fulfill your needs (Maudodi, 1999:280). After the revelation of the verse of Hijab, Hazrat Aisha practice veil, whenever she came out of her home. She could not stop coming of intelligent students to her home for study. According to the instructions of the Holy Prophet PBUH, she used curtains between her and the students. At the time of Hajj women asked Hazrat Aisha to come along with them to kiss Hijr-eAswad. Hazrat Aisha told them that they could go without her because she was not allowed to go into the crowd of men. When at daytime when she wanted to have Tuaf - e - Kaba the men were being sent out of Khana - e - Kaba and Hazrat Aisha used to cover her face fully. Ishaq Tabi (Sahabi) a blind man when came to meet her. She put on veil to meet him. He said, "I am a blind man, why did you put on veil". She replied that you are a blind but I am not. I can see you even if you cannot see me. Syed Suleman Nadvi in his book characteristics of Hazrat Aisha wrote that although in Sharia there is no veil from dead persons, but she never went to her room where Hazrat Umer was buried after his death (Nadvi, 2005:148). Hazrat Aisha's personality whose follower's women are sure to go to heaven and they can be respected and has a noble status in the world.

In light of teaching of Islam there are two schools of Muslim (thought) scholars. One is in favor of complete veiling of women and another is not. Those who favor veil are providing references of the Holy Quran and Hadits in favor of their opinion that all parts of women body must be fully covered. Second groups comprising on those who are in favor of women veil but they agreed that woman can take her face and hands out of the veil to perform her daily activities and essential work of her life. Because several socioeconomic and religious duties and functions cannot be performed in veil so they are bound to unveiled face and both hands. Incase if all parts of woman's body are fully covered she must be in a big trouble fulfilling her daily duties. Therefore, they can unveiled their face and hands for doing work, but while unveiling them (face and hands) Allah has order for a woman that eyes of a woman should be downwards. In Sura-e-Al Ahzab Allah says, O prophet tell your wives and daughters and Muslim women to put on 
themselves their Chader (shawls), it is good to be recognized by others, rather to be teased by others (Sura-e-Al Ahzab:59).

\section{Research Objectives}

This article aims at: (1) historical background of veil and its existence in different civilizations, (2) Socio-Economic impact of it on women, (3) Meaning and interpretation of veil in Islamic context. Articles, books, research papers, personal experiences and observations were used in this research.

\section{Methodology}

The study is based on the two main types of data. Articles, books, research papers, library research, personal experiences, observations and previous literature which provide indepth knowledge about the controversy of veil in the eastern as well as western countries. Previous literature is used for in-depth background of Islamic perspective of veil.

\section{Discussion}

Veil in Muslim women is a pivotal point of argument in the Western countries. According to (Hoodfar, 1991; Yegenoglu, 1998 Kahf, 1999; Read \& Bartkowski, 2000) veil is a very controversial phenomenon in Western societies. Where such an ethnocentric universalism prevails, we see the creation of artificial social categories. Western women rights-activists are generally presented as the subjects of this counter history and the third world monolithic of colored and 'covered' women are rarely depicted as rising above the silencing generality of being 'Other' (Abu-Lughod, 2002).

Among the civilized societies, there are two motives or notions of sexual relations. First is to have an offspring to become a father or parents, and have children and second is based on love for chastity but being contaminated with sexual lust and can be called a faith on living a life as an unmarried, a celibate, bachelor in case of men and or virgin in case of a woman. According to (Bertrand Russell) the sexual relations in the world till to date ever since the humankind existed are based on the first motive. However, India and Persia are based on the second motives because there is veil existing between men and women and sexual relationships have abstinence (Russell; 1872-1921:138).

When eastern nations discussed veil as a biggest obstacles in the progress of Muslims, and they made it realized to Muslims that it was a real cause of their backwardness. In the meanwhile when Muslims discussed progress of eastern nations and freedom of women, they thought that their women should adopt the way of life of the western nations. Although there is a clear instruction about veil in the holy Quran, in Europe discussions 
and conferences started to get the opinion for abandoning use of veil among the Muslims families. When Muslim families in western nations started allowing their women-folk to follow culture of the western women then family system in eastern nations started weakening and disappearing. Muslims started thinking and discussing about its impact on their existence. The civilizations e.g. Cyprus and Romans who had lost distinctions between men and women vanished from the map of the world. In Islam Muslim women and men are equal and performing their due roles that separate them from each other. The mighty nations and civilizations that were highly successful and, ruled over the entire world were also sociologically and ethically highly civilized. However, when slowly they adopted unethical, sexual and psychological motives they lost all their might.

Islam is a religion that does not allow men and women to be unmarried and live a life of a monk rather encourages living successful life full of enjoyment. It allows men and women to benefit from the bounties of the world. The Islamic the physical outlook and appearance of woman and men should not attract others and be objectionable for them. Women are more than $50 \%$ of the population they are more attractable than the men are. They must come out in open spaces in such a manner that increases their respect. Islam has defined boundaries for woman. Every Muslim woman must follow them.

Islam allows women to perform daily duties and for doing them, they are encouraged and allowed to come out of their homes. She is allowed to study in co-education institutions. She can work in organizations and institutions to earn, satisfy, and fulfill her needs and wants of daily life. She has a right to fulfill her socio-cultural and economic needs and requirement of living. Allah has given a right of freedom in sphere of life. This freedom has some responsibilities and it is based on certain conditions. These conditions are based on the natural responsibilities and situation (Khomeinism: Essays on Islamic Republic, Berkeley, CA: University of California Press.)

Before the advent of Islam women used to go out unveiled. Having made up that use to attract men, these women were teased by some men (Sura-e-Al Ahzab, 23). Taking into consideration such situation was not acceptable therefore, Allah advised and forbidden that women must cover their body and attractable parts to be respected by others when they come out in public. After revelation of the verses regarding veil of women, women of the family of the Holy prophet used to cover their body whenever came out in a public even at the time of Hajj they veiled themselves during Hajj and Tuaf Kaba. They used to preach in public to Muslims in open spaces. They were allowed to unveiled their face and hands at the time of Hajj so that others can recognize them and be respected by them instead of being teased (Sheikh, 1987:127). Women are allowed to go out and perform their work but in an ethical dress. To create peace in society women are bound to make up themselves according to Islamic guidelines. As reported by research based on interviews, many women choose to wear the headscarf in order to fulfill not only 
religious, but identity, cultural, social and political needs too. (Misha \& Shirazi, 2010) find out that Muslim women practice of veil for religious identity while (Peek, 2005) argue that Muslim practice it to select their identity as American as Muslim. (Misha \& Shirazi, 2010) find out that women supposed that veil protect their identity.

\section{Conclusions}

In a particular situation woman has to decide when she has to veil and when not. In teaching of Islam, there are no clear instructions for veiling of hands and face (Maudodi, 1999:266). Allama Iqbal the poet of east has also advised women to follow Islamic teachings in daily life. A mature pious (Momin) Muslim women is fully respected having trust on Allah and confidence on herself she must also make her own decisions and Judgments to follow instructions and decide when to veil and not to perform her duties and daily matter of life (Soharwardi, 2001:293). Lives of Muslim women are depending on their religious conditions, position, and communal status. However, it is still very much limited for women, depending on how much Muslim women is prepared to sacrifice within her society for the sake of heaven while other societies is often just a case of sacrificing her femininity.

\section{References}

Abu-Lughod, L. (2002). Do Muslim women really need saving? Anthropological Al Quran, 21:23.

Afary, Janet (1996). The Iranian Constitutional Revolution, 1906-1911. New York: Columbia University Press. Muhammad 1995, E1-Guindi’s, 1992.

Afshar, Haleh. (1985). The Legal, Social and Political Position of Women in Iran. International Journal of the Sociology of Law, vol.13, pp.47-60.

Afzal-Khan, F. (2007), Betwixt and between? Women, the Nation and Islamization in Pakistan, Social Identities, vol.13:1, pp.19-29.

Ahmed, L. (1992). Women and Gender in Islam. London: Yale University Press.

Al-Qur'an Surrah Al-Nur, Verse 24:31.

Al-Qur'an Sure -Al- Ahzab, 23. 
Ali, S. \& Bagheri, E. (2009). Practical Suggestions to Accommodate the Needs of Muslim Students on Campus. New Directions for Student Services, vol.125, pp.47-54.

Ali, S. H. (2005), Why here, why now? Young Muslim Women Wearing Hijab, The Muslim World, vol.95:4, pp.515-530. As Popular Culture and Symbol of Political Confrontation in Modern Turkey, Journal of Popular Culture, vol.33:4, pp.25-38.

Balkhair, Leila, (2010). Women Issues in the Age of Globalization, (Arabic) Modern Book world, Irbid, p.20.

Bayat, A. (2007). Making Islam Democratic, Stanford University Press, Stanford, CA.

Baydoun, Taghreed. (1985). Women and the Social Life in Islam, (Arabic,), Dar AlNahda, Press, Beirut, p.111.

Blaydes, L. \& Linzer, D. (2008). The Political Economy of Women's Support for Fundamentalist Islam', World Politics, vol.60:4.

Brenner, Suzanne. (1996). Reconstructings Elf and Society: Javanese Muslim Women and the Veil. Ameri-can Ethnologist, vol.23, pp.673-97.

Cutrufelli, M.R. (1983). Women of Africa: Roots of Oppression. London: Zed Press.

Droogsma, R. (2007). Rede_Ning Hijab: American Muslim Women's Standpoints on Veiling', Journal of Applied Communication Research, vol.35:3, pp.294-319.

Dwyer, C. (1999). Veiled Meanings: Young British Muslim Women and the Egotiation of Differences. Gender, Place \&Culture, vol.6:1, pp.5-26.

El Guindi, Fadwa (1999). Veil: Modesty, Privacy and Resistance. Oxford: Berg.

Elwan, Anan. (1989). The Conditions of Muslim Women's Work (Arabic), in Asma, vol.4, p. 63 .

Esposito, John L. ed. (1995). The Oxford Encyclopedia of the Modern Islamic World. New York: Oxford University Press.

Fontana, A. \& Frey, J. H. (2005). The Interview: From Mental Stance to Political Involvement. In N. K. Denzin \& Y. S. Lincoln (Eds), The Sage Handbook of Qualitative Research (3rd. edn.). Thousand Oaks, CA: Sage. 
Goto, E. (2004). Quar'an and the Veil: Contexts and Interpretations of the Revelation, International Journal of Asian Studies, 1:2, pp.277-295.

Greaber, David (2011) Debt: The First 500 Years, Brooklyn, New York: Melville. House.

Gruenbaum, E. (1991). The Islamic Movement, Development, and Health Education: Recent.

Guindi, EI, Fedwa (1999). Veil: Modesty, Privacy a Resistance, New York: Haven Yale University Press.

Halliday, F. (1994). The Politics of Islamic Fundamentalism. In A. Ahmed and H. Donnan Eds.), Islam, Globalization and Postmodernity (pp. 91-113). London: Routledge.

Hargreaves, J. (2000). Heroines of Sport: The Politics of Difference and Identity. London: Routledge.

Hargreaves, J. \& Vertinsky, P. (2007). Physical Culture, Power and the Body. London \& New York: Routledge.

Hessini, Leila. (1994). Wearing the Hijabi contemporary Morocco: Choice and Identity. In Reconstructing Gender in the Middle East: Tradition, Identity, and Power, edited by F. M. Gocek and S. Balaghi. New York: Columbia University Press.

Hoodfar, H (1991). The Veil in their Minds and on Our Heads: The Persistence of Colonial Images of Muslim Women. Resources for Feminist Research/ Documentation sur la Recherché Feminist (RFR/DFR) vol.22:3-4, pp.5-18.

Hourani, A. (2005), A History of the Arab Peoples, Faber and aber, London, UK.

Hughes, Lisa A. (2007) Unveiling the Veil: Cultic, Status and Ethnic Representatives of Early Freedwoman. The Journal of Objects, Arts and Belief, vol.3, pp.218-241(24) $2^{\text {nd }}$ July 2007.

Kadioglu, Ayse. (1994). Women's Subordination in Turkey: Is Islam Really the Villain? Middle East Jour-nal, vol.48, pp.645-60.

Kahf, M. (1999). Western Representations of the Muslim Woman: From Termagant to Odalisque. Austin, TX: University of Texas Press. 
Knauss, Peter R. (1987). The Persistence of Patriarchy: Class, Gender, and Ideology in Twentieth Century Algeria. New York: Praeger.

Macleod, Arlene Elowe, (1991). Accommodating Protest: Working Women, the New Veiling, and Change in Cairo. New York: Columbia University Press.

Mahl, M. (1995). Women on the Edge of Time. New Internationalist, August: pp.14-16.

Maudodi, Maulana Syed Abu-al-Ali (1999) Veil, Lahore: Islamic Publications Ltd.

Mernissi, F. (1991). The Veil and the Male Elite: A Feminist Interpretation of Women's Right in Islam. New York: Perseus Books.

Mernissi, Fatima (1987). Beyond the Veil. Rev. ed. Bloomington: Indiana University Press.

Misha, S., Shirazi, F. (2010). Hybrid identities: American Muslim Women Speak. Gender, Place and Culture, vol.17:2, pp.191-209.

Morin, R. \& Horowitz, J. M. (2006). Europeans Debate the Scarf and the Veil, Pew Global Attitudes Report.

Moududi, A.A. Tafheem-ul-Quran. Lahore: Tarjuman-al-Quran, (1972). Mughal, Z. and J.A. Ansari. Microeconomics: Theory, Practice and Evaluation. Karachi: University of Karachi Press, 2011.Muslim Societies. London: Zed Press.

Nadvi, A.B. (2005) Ma'shiyat ka Islami Falsafa. Multan: Idara Talifat-e- Ashrafiya.

Nadvi, S.A. (1954) Tareekh-e-Dawat-o-Azeemat. Karachi: Majlis-e- Nashriyat-e-Islam.

Nashat, Guity, (2003b). Women in Pre-Islamic and Early Islamic Iran. In Nashat and Beck Negotiation among Muslim Women in Austin, Texas. Gender and Society, vol. 14.

Nehru, Jawal Lal (1950). The History of the World, New Delhi: Oxford Publishers. No. 3, pp.783-790.

Odeh, Lama Abu (1993). Post-colonial Feminism and the Veil: Thinking the Difference. Feminist Review, vol.43, pp.26-37. 
Omkar, K. (2007). Between Being and Believing: Understanding Veiling amongst British Muslim Women, Master's thesis, Department of Sociology, University of Oxford.

Papanek, Hanna \& Minault, Gail. (Eds.). (1982). Separate Worlds: Studies in Purdah in South Asia. New Delhi: Chanakya Publications. Rozario.

Peek, L. (2005). Becoming Muslim: The development of a religious identity. Sociology of Religion, vol.66:3, pp.215-242.

Razack, S. H. (2004). Imperiled Muslim Women, Dangerous Muslim Men and Civilized.

Reeves, Minou, (1989). Female Warriors of Allah: Women and the Islamic Revolution. New York: Dutton.

Rheault, M. (2008). Headscarves and Secularism: Voices from Turkish Women, Gallup World Poll report.

Rug Veda, Book \# 8 Hymn 85, mantra 33.

Russell Bertrand, (1872-1921). Marriage and Characters, London: Oxford press.

Schmidt, Alvin J. (1989). Veiled and Silenced: How Culture Shaped Sexist Theology. Macon, GA: Mercer University Press.

Sheikh, Ali Muhammad, (1987). Islam and New Thinking. Karachi: Islamic Book Corporation.

Sherif, Mostafa H. (1987). What is Hijab? The Muslim World, vol.77, pp.151-63.

Soharwardi, Abdul Hammed Maulana (2001). Rehabber Kama, Muslim Publishers.

Smith-Hefner, N. (2007). Javanese Women and the Veil in Post-Soeharto Indonesia, Journal of Asian Studies, vol.66:02, pp.389-420.

Stillman, Y. (2003). Arab Dress: A Short History from the Dawn of Islam to Modern Times, E.J Brill, Leiden, Netherlands.

Waltz, S. (1986). Islamist Appeal in Tunisia, Middle East Journal, vol.40:4, pp.651-670.

Williams, Rhys H. \& Gira Vashi. (2007). Hijab and American Muslim Women: Creating the Space for Autonomous Selves." Sociology of Religion, vol.68:3, pp.269-287. 
Williamson, W. P. \& Ahmad, A. (2007). Survey Research in Islamic Fundamentalism: A Question about Validity. Journal of Muslim Mental Health, vol.2:2, pp.155-176.

Yegenoglu, M. (1998). Colonial Fantasies: Towards a Feminist Reading of Orientalism. Cambridge, UK: Cambridge University Press.

\section{WEBLIOGRAPHY}

www.britannica.com/place/United-States-Year-In-Review-2000

Shagufta Jahangir is Ph.D Student in the Centre of Excellence for Women's Studies, University of Karachi.

Dr. Asma Manzoor is an Assistant Professor in the Centre of Excellence for Women's Studies, University of Karachi.

Dr. Mufti Imran ul Haq Kalyanvi is an Assistant Professor in the Department of Quran-o-Sunnah, University of Karachi. 